\title{
NEO-KAJANG: SEBUAH TIPOLOGI BARU PEMUKIMAN EKOLOGIS BAGI KOMUNITAS SUKU LAUT
}

\author{
Octaviany $^{1)}$, Alvin Hadiwono ${ }^{2)}$ \\ 1)Program Studi S1 Arsitektur, Fakultas Teknik, Universitas Tarumanagara, viany257@gmail.com \\ 2) Program Studi S1 Arsitektur, Fakultas Teknik, Universitas Tarumanagara, alvinh@ft.untar.ac.id
}

\begin{abstract}
Abstrak
Perkembangan kota sekarang ini tidak segalanya mengarah kearah positif. Karena pertumbuhan kota yang terlalu cepat dan tidak terencana dapat menimbulkan perubahan terhadap pola hidup, pengetahuan, lokalitas, identitas, dll. Suku Laut merupakan masyarakat yang dikenal biasa hidup di atas sampan yang dinamakan kajang. Namun sejak tahun 1990-an, Suku Laut ditempatkan pada posisi yang marjinal dan juga tidak mengenal peradaban dan modernitas, sehingga dikategorikan sebagai suku terasing. Oleh sebab itu, Suku Laut menjadi sasaran dalam agenda pemerintah, yaitu dengan membatasi akses mereka terhadap laut dan membuatkan pemukiman untuk mereka. Hal itu memaksa Suku Laut untuk menjalani pola hidup yang berbeda dengan yang dulu biasa mereka jalani, membawa diri mereka kepada kesadaran baru "kesadaran sebagai Suku Laut yang mendarat" dan menyebabkan munculnya nilai-nilai baru, perubahan spatial behavior (livehood, organisasi sosial, dll). Proyek ini menggunakan metode hibrida dengan parameternya, yaitu Filosofi Simbiosis Suku Laut dan Beyond Ecology yang diterapkan didalam perancangan. "Neo-Kajang" artinya "Melampaui-Kajang", Kajang merupakan istilah dari tempat tinggal Suku Laut, Sedangkan "Tipologi Baru Pemukiman Ekologis Suku Laut", berarti mengadaptasi perjalanan dan cara hidup Suku Laut ke dalam tipologi yang baru untuk menjawab tantangan zaman. Proyek ini juga diharapkan mampu mengangkat cara hidup Suku Laut dalam menghadapi perubahan zaman dimana sejatinya. Suku Laut merupakan salah satu contoh nyata tentang filosofi hidup effisien dan berdamai dengan lingkungan, khususnya wilayah kemaritiman.
\end{abstract}

Kata kunci: beyond ecology; modernitas; suku laut; tipologi baru.

\begin{abstract}
The development of the city today is not all in a positive direction. urban growth that is too fast and unplanned, it can cause changes to lifestyle, knowledge, locality, identity, etc. The Sea Nomad is a community that is known to live on a canoe called a kajang. However, since the 1990s, the Sea Nomad has been placed in a marginal position and also does not know civilization and modernity, so it is categorized as an isolated Nomad. Therefore, the Sea Nomad became a target in the government's agenda, namely by limiting their access to the sea and building settlements for them. This forces the Sea Nomad to live a different lifestyle from the one they used to live, bringing themselves to a new awareness of "awareness as a landed Sea Nomad" and causing the emergence of new values, changes in spatial behavior (livehood, social organization, etc.). ). This project uses a hybrid method with parameters, namely the Symbiosis Philosophy of Sea Nomad and Beyond Ecology which are applied in the design. "Neo-Kajang" means "Beyond-Kajang", Kajang is the term for where the Sea Nomad live, while "New typology of marine tribal ecological settlements" means adapting the journey and way of life of the Sea Nomad into a new typology to answer the challenges of the times. This project is also expected to be able to elevate the way of life of the Sea Nomad in the face of changing times where in fact the Sea Nomad is a real example of the philosophy of living efficiently and at peace with the environment, especially the maritime area.
\end{abstract}

Keywords: beyond ecology; modernity; new typology; sea tribes. 


\section{PENDAHULUAN}

\section{Latar Belakang}

Perkembangan kota saat ini menyebabkan perubahan terhadap paradigma pembangunan di berbagai negara, termasuk Indonesia. Pertumbuhan kota yang terlalu cepat dan tidak terencana dapat menimbulkan perubahan terhadap pola hidup, pengetahuan, lokalitas, identitas, dll. Salah satunya seperti yang terjadi di dalam masyarakat Suku Laut.

Suku Laut disebut sebagai Sea Nomads, dikarenakan Suku Laut hidup nomaden dengan melakukan seluruh aktifitasnya diatas sampan yang dinamakan kajang. Kehidupan Suku Laut bergantung pada laut dan juga masih tradisional, dan mereka dikenal tidak menganut agama atau animisme. Dengan sampan/kajang, Suku Laut mengajarkan kepada anak serta cucu mereka tentang bagaimana dari hidup sampai kematian di atas laut. Laut merupakan sumber kehidupan dan perjalanan hidup bagi Suku Laut. Sejak tahun 1990-an, Suku Laut ditempatkan pada posisi yang marjinal dan juga tidak mengenal peradaban dan modernitas, sehingga dikategorikan sebagai suku terasing. Oleh sebab itu, Suku Laut menjadi sasaran dalam agenda pemerintah, yaitu dengan membatasi akses mereka terhadap laut dan membuatkan pemukiman untuk mereka.

Oleh sebab itu, Suku Laut menjadi sasaran proyek pembangunan pemerintah Indonesia, yaitu memodernkan Suku Laut dengan membatasi akses mereka terhadap laut, dan membuatkan pemukiman untuk mereka. Suku Laut juga menjadi terikat dengan regulasi yang mengatur mobilitas mereka, terutama ketika mereka harus melintasi batas-batas Negara (Chou, 2009).

Tentunya dengan memukimkan Suku Laut di pulau-pulau tertentu telah membawa berbagai dampak terhadap kehidupan sosial-budaya Suku Laut. Hal itu memaksa Suku Laut untuk menjalani pola hidup yang berbeda dengan yang dulu biasa mereka jalani, membawa diri mereka kepada kesadaran baru "kesadaran sebagai Suku Laut yang mendarat" (Prawirosusanto, 2015). Dalam hal ini, dapat terlihat Suku Laut di Kepulauan Riau mengalami pergeseran diakibatkan oleh agenda pembangunan (perkembangan kota) dan sejauh mana mereka dapat mengadopsi gaya hidup orang darat yang berbeda dengan gaya hidup mereka dulunya di sampan/kajang. Oleh sebab itu berbagai konsekuensi mengenai pola hidup, teritorial, mode produksi, lokalitas dan identitas menjadi isu utama, terlebih dengan masalah -masalah lingkungan/ekosistem yang terjadi ketika mereka hidup di darat.

Dalam konsep dan implementasi pembangunan yang berkelanjutan, Suku Laut merupakan salah satu contoh nyata tentang filosofi hidup effisien dan berdamai dengan lingkungan, khususnya wilayah kemaritiman. Sejauh mana kearifan lokal ini dapat bertahan sangat tergantung kepada sajauh mana mereka bisa mempertahankan persepsi terhadap lingkungan yang sekarang ada dari terpaan arus modernisasi dan globalisasi yang sering tidak berpihak terhadap lingkungan dan bahkan mengubah pola kehidupan suatu masyarakat itu sendiri.

\section{Rumusan Permasalahan}

Modernitas menyebabkan Suku Laut menjadi sasaran dalam agenda pemerintah, yaitu dengan membatasi akses mereka terhadap laut dan membuatkan pemukiman untuk mereka. Tentunya dengan memukimkan Suku Laut di pulau-pulau tertentu telah membawa berbagai dampak terhadap kehidupan sosial-budaya dan lokalitas Suku Laut. Hal itu memaksa Suku Laut untuk menjalani pola hidup yang berbeda dengan yang dulu biasa mereka jalani. Melalui "Tipologi baru pemukiman ekologis Suku laut", berarti mengadaptasi perjalanan dan cara hidup Suku Laut ke dalam tipologi yang baru untuk menjawab tantangan zaman. 


\section{Tujuan}

Proyek ini mempertanyakan bagaimana arsitektur dapat mengakomodir kebutuhan Suku Laut dengan lokalitasnya di modernitas ini. Proyek ini juga diharapkan mampu mengangkat cara hidup Suku Laut dalam menghadapi perubahan zaman dimana sejatinya. Melalui "Tipologi baru pemukiman ekologis Suku laut", berarti mengadaptasi perjalanan dan cara hidup Suku Laut ke dalam tipologi yang baru untuk menjawab tantangan zaman. Suku Laut merupakan salah satu contoh nyata tentang filosofi hidup efisien dan berdamai dengan lingkungan, khususnya wilayah kemaritiman.

\section{KAJIAN LITERATUR}

\section{Ekologi}

Kata "Ekologi" diciptakan oleh seorang ahli biologi Jerman pada tahun 1869 dan berasal dari kata Yunani, "Oikos" yang berarti "Rumah". Ekologi adalah cabang ilmu yang berhubungan dengan studi tentang interaksi antara organisme hidup dan fisiknya lingkungan hidup. Keduanya terkait erat dan mereka memiliki interaksi terus menerus sehingga terjadi perubahan lingkungan yang berpengaruh pada organisme hidup dan sebaliknya (De \& De, 2009).

\section{Deep Ecology}

Menurut Bill Devail George dalam bukunya yang membahas tentang Deep Ecology mengatakan, meskipun ekologi dipandang dan diakui sebagai sebuah ilmu sains, ekologi sendiri memiliki makna universal yang lebih besar dan utama. Pengetahuan ini dapat ditinjau dari berbagai macam hal. Deep Ecology sangat konservatif dan memiliki hubungan serta wawasan yang kuat mengenai banyak kepercayaan dan filosofis tentang manusia purba (Devall, 1985).

\section{Beyond Ecology dalam Arsitektur}

Berikut adalah beberapa unsur dari Beyond Ecology (Sutanto, 2020):

- Energy and Emission

Mengolah dan meminimalisir hasil emisi yang dihasilkan oleh bangunan dengan penerapan desain dan penggunaan material serta organisasi ruang.

- Adaptation Architecture

Melakukan penelitian atau riset mengenai dampak yang terjadi terhadap lingkungan, seperti pengaruh perubhana iklim global dan lain-lain.

- Resilience Architecture

Kemampuan bangunan bertahan dan menghadapi masalah-masalah yang akan terjadi ke depannya.

- Suistainable Digital Architecture

Mampu mengolah data-data lingkungan sekitar sebagai acuan dan strategi baru dalam menentukan sebuah ruang

- New Technology

Pemanfaatan teknologi terbaru dalam ruang, program dan material dalam bangunan.

- Context

Kontekstual terhadap letak dan pengaruh hubungan terhadap lingkungan sekitar dimana sebuah spasial ditempatkan.

\section{Filosofi dari Lokalitas Arsitektur}

Lokalitas bukanlah sebuah gaya atau langgam dalam arsitektur. Lokalitas adalah sebuah 'gerakan' yang memperjuangkan identitas kelokalan ditengah arus globalisasi. Lokalitas bergerak dan hidup dalam 'serangan' modernitas dan 'gelombang' globalisasi, yang akhirnya membuat 'terpinggirkan`. Namun dalam perkembangannya, ketika dunia menjadi begitu 
menjadi modern dan universal, kerinduan akan nilai-nilai kelokalan masih terus digali dan dicari serta dianggap sebagai kekuatan keruangan yang memiliki aura identitas dan karakter sebuah tempat. Sebagai sebuah 'gerakan', lokalitas mengusung dua narasi besar didalamnya yaitu Vernakular dan Tradisional.

Filosofi tertinggi dari lokalitas arsitektur adalah tidak merusak alam. Pada dasarnya ada tiga komponen, yaitu manusia, budaya, dan alam. Manusia menghasilkan desain, desain yang dihasilkan selalu berhadapan dengan alam. Lokalitas dan arsitektur dapat ditunjukkan bahswa desain yang memakai pendekatan ekologis harus selalu memenuhi tiga kriteria, adaptasi dengan alam, adopsi dari alam (mengambil bentuk dari alam) dan akomodasi alam (melengkapi alam) (Sutanto, 2020).

\section{Arsitektur Neo Vernakular}

-Pengertian Neo Vernakular

Kata Neo atau New berarti baru atau hal yang baru, sedangkan kata vernacular berasal dari kata vernaculus (bahasa Latin) yang berarti asli. Arsitektur Neo Vernakular merupakan suatu paham dari aliran Arsitektur Post-Modern yang lahir sebagai respon dan kritik atas modernisme yang mengutamakan nilai rasionalisme dan fungsionalisme yang dipengaruhi perkembangan teknologi industri.

Arsitektur Neo-Vernakular merupakan arsitektur yang konsepnya pada prinsipnya mempertimbangkan kaidah - kaidah normatif, kosmologis, peran serta budaya lokal dalam kehidupan masyarakat serta keselarasan antara bangunan, alam, dan lingkungan (Sudikno, 2017).

- Prinsip - Prinsip Desain Arsitektur Neo-Vernakular

Prinsip-Prinsip Desain Arsitektur Neo-Vernakular :

- Hubungan Langsung

Merupakan pembangunan yang kreatif dan adaptif terhadap arsitektur setempat yang disesuaikan dengan nilai-nilai/fungsi dari bangunan sekarang.

- Hubungan Landscape

Mencerminkan dan menginterpretasikan lingkungan seperti kondisi fisik termasuk topografi dan iklim.

- Hubungan Kontemporer

Meliputi pemilihan penggunaan teknologi, bentuk ide yang relevan dengan program konsep arsitektur.

- Hubungan Masa Depan

Merupakan pertimbangan mengantisipasi kondisi yang akan datang (Studio, 2020).

\section{Arsitektur Simbiosis}

Arsitektur simbiosis adalah konsep pendekatan yang ada terinspirasi oleh proses biologis. Simbiosis berasal dari kata 'sim' dan 'biosis' yang artinya timbal balik hubungan antara dua elemen yang berdampingan.

Proses simbiosis berfungsi untuk melestarikan elemen yang berbeda tetapi berdampingan sisi. Konsep tersebut diimplementasikan dalam arsitektur oleh Kisho Kurokawa pada tahun 1960. Menurut Kisho Kurokawa, itu penggabungan 2 elemen berbeda dalam arsitektur diperlukan untuk menjaga kelestariannya masing-masing.

Konsep tersebut diimplementasikan dalam arsitektur oleh Kisho Kurokawa pada tahun 1960. Menurut Kisho Kurokawa, itu penggabungan 2 elemen berbeda dalam arsitektur diperlukan 
untuk menjaga kelestariannya masing-masing. Konsep simbiosis berasal dari bahasa Jepang tradisional filosofi arsitektur yang menerapkan kolaborasi antar elemen modern dan elemen tradisional. Berikut adalah komponen dasar dari filosofi simbiosis:

- Simbiosis dari kebudayaan yang heterogenya.

- Simbiosis manusia dan teknologi.

- Simbiosis interior dan eksterior.

- Simbiosis sejarah dan masa depan.

- Simbiosis religi dan ilmu pengetahuan.

- Simbiosis arsitektur manusia dan alam (Widagdo, Kusumarini, \& Basuki, 2013).

\section{METODE}

Metode penelitian yang digunakan adalah kualitatif. Pengumpulan data, melaui studi literatur yang sudah ada. Hibrida adalah salah satu metode perancangan arsitektur yang muncul di era post-modern. Hibrida juga merupakan kombinasi dari beberapa elemen yang berbeda, diprakarsai oleh Kisho Kurokawa pada tahun 1960, sebagai perkembangan dari konsep arsitektur simbiosis.

Berikut adalah komponen dasar dari filosofi simbios Suku Laut:

- $\quad$ Tipologi suku laut

- Fungsi dan kebudayaan

- Manusia dan Teknologi

- Timeline Kebudayaan dan keseharian

Strategi desain yang akan digunakan Filosofi Simbiosis Suku Laut dan Parameter Beyond Ecology yang di terapkan didalam perancangan.

\section{Filosofi Simbiosis Suku Laut}

- Tipologi Suku Laut

Pola Permukiman

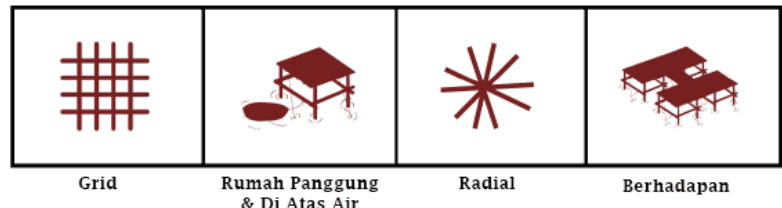

Bentuk Massa

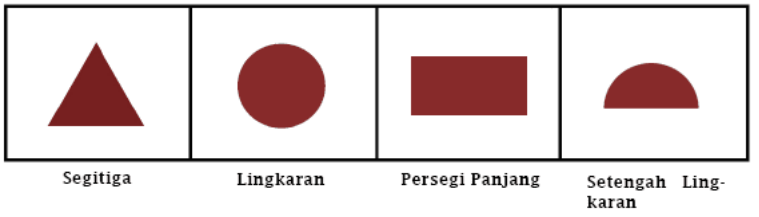

Penghubung

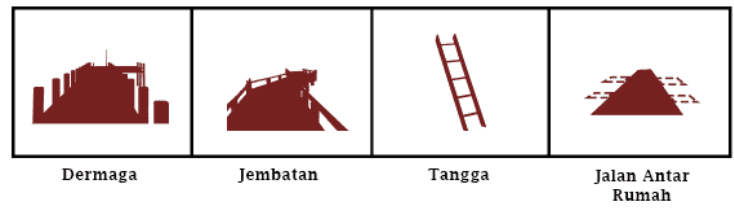

Lalu Lintas (Transportasi) Material

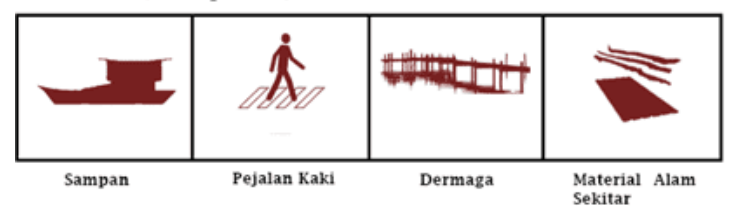

Gambar 1. Tipologi Suku Laut Sumber: Penulis, 2021 
-Fungsi \& Kebudayaan
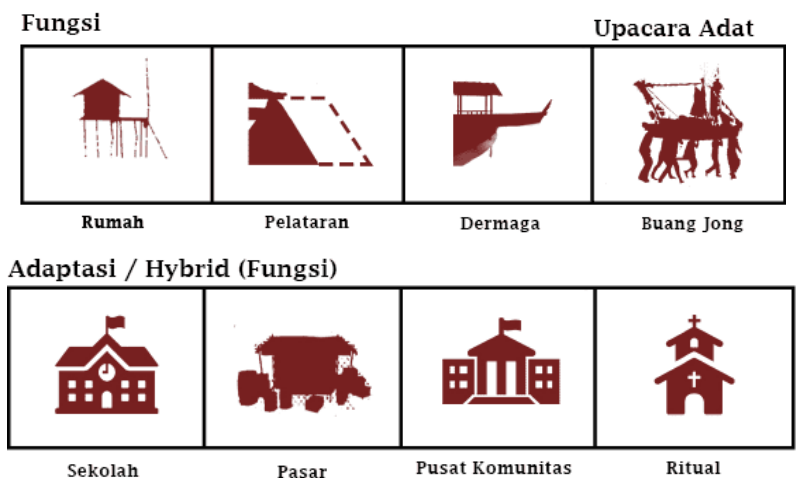

Gambar 2. Fungsi dan Kebudayaan Suku Laut Sumber: Penulis, 2021

-Teknologi

Teknologi yang digunakan :

\section{Fog water harvesting}

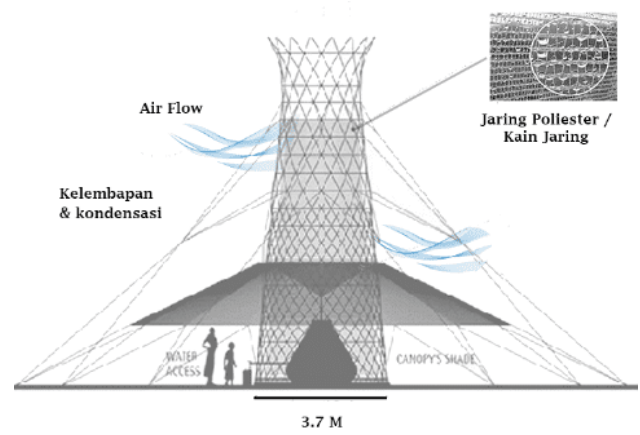

Gambar 3. Ilustrasi Fog Waterharvesting

Sumber: www.engineeringforchange.org

\section{Aquakultur restoratif}

Kerang \& Rumput Laut keduanya berfungsi untuk meningkatkan kualitas air secara alami dan menyaringnya, ketika mereka menyerap sinar matahari dan nutrisi dari air laut. Dengan menyerap karbon melalui fotosintesis, perikanan tersebut membantu memerangi perubahan iklim, dan mengurangi pengasaman laut lokal sementara juga menciptakan habitat bagi spesies lain untuk berkembang. Dalam 5 bulan (4000m2) biasanya dapat menghasilkan 25 Ton Rumput laut dan 250000 kerang.

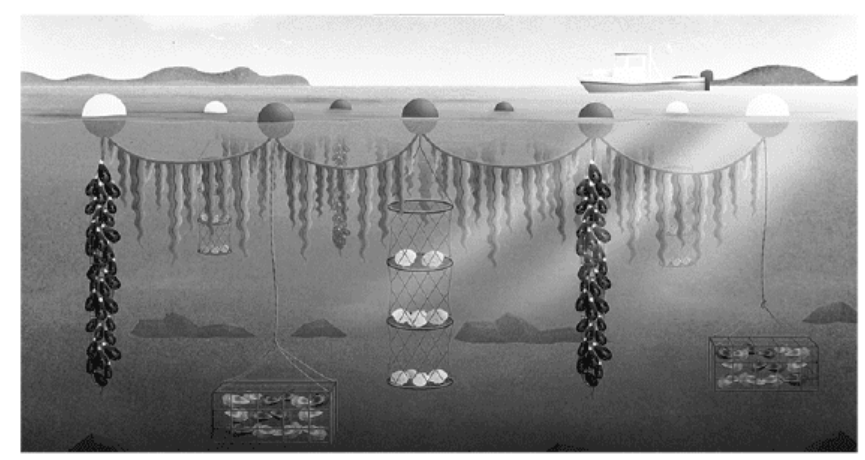

Gambar 4. Ilustrasi Aquakultur Restoratif Sumber: Johnson \& Davis, 2019 


\section{Anaerobic Digester}

- Semua limbah ikan yang dihasilkan dari perikanan termasuk isi perut, tulang dan produk limbah dari proses minyak ikan cod dikumpulkan dan ditambahkan ke digester anaerobik. - Digester anaerobik berisi semua limbah ikan dari perikanan. Kapal tertutup memungkinkan proses alami biodegradasi terjadi di lingkungan bebas oksigen

- Biogas diproduksi melalui penguraian bahan organik. Gas dapat terbakar jika bercampur dengan oksigen, energi yang dilepaskan dari proses ini memungkinkan biogas digunakan sebagai bahan bakar untuk pemanasan dan keperluan lainnya.

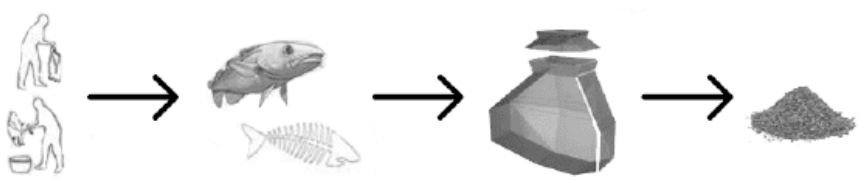

Gambar 5. Ilustrasi Anaerobic Digester

Sumber: worldarchitecture.org

- Timeline Kebudayaan dan keseharian

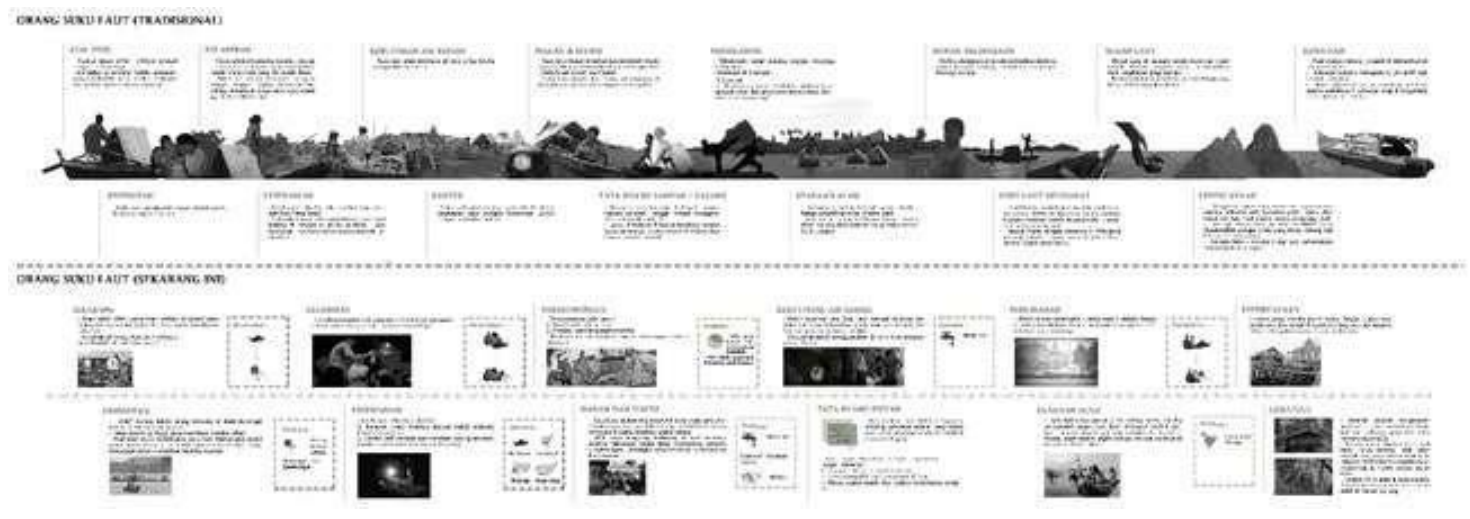

Gambar 6. Simbiosis Timeline Kehidupan Suku Laut Sumber: Penulis, 2021

\section{Parameter Beyond Ecology}

\section{- New Technology}

Pengaplikasian "Fog Waterharvesting" untuk menjawab penyelesaian masalah air bersih yang terjadi pada Suku Laut dengan memanfaatkan kelembapan dan curah air hujan untuk menjadi sumber air bersih bagi Suku Laut Sedangkan untuk "Aquakultur Restoratif” diharapkan dapat membantu penghasilan nelayan apabila musim panen ikan sedang menurun.

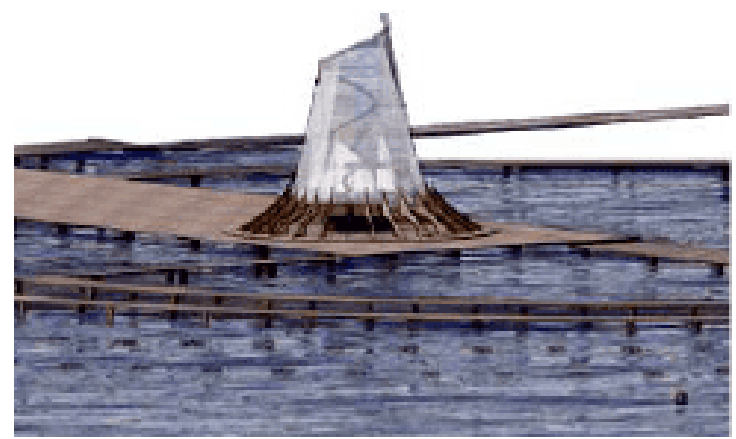

Gambar 7. Fog Waterharvesting \& Aquakultur Restoratif Sumber: Penulis, 2021 


\section{- Context}

Menciptakan pemukiman yang terikat dengan laut agar tetap terjalin interaksi antara Suku Laut dengan alam nenek moyang.

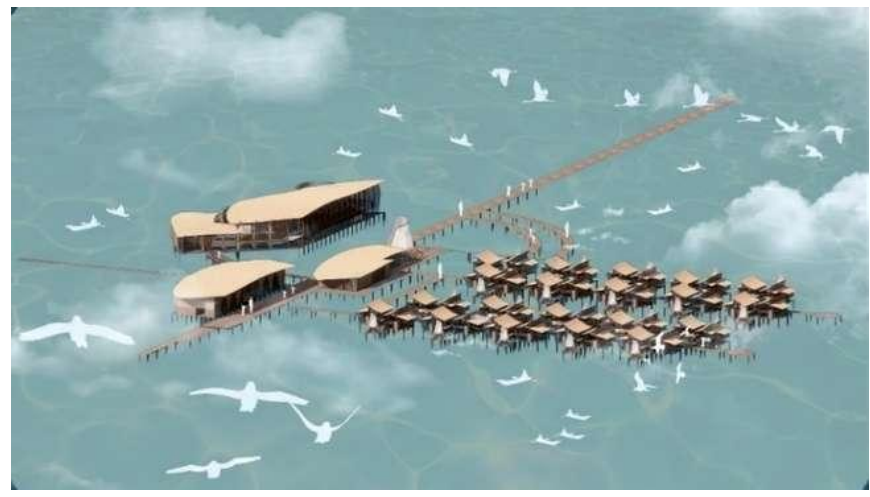

Gambar 8. Pemukiman Suku Laut

Sumber: Penulis, 2021

\section{- Energy \& Emisson}

Penerapan material alami seperti kayu, daun sagu/nipah, dll sebagai bahan utama pembangunan dan meminimalisir penggunaan energi,

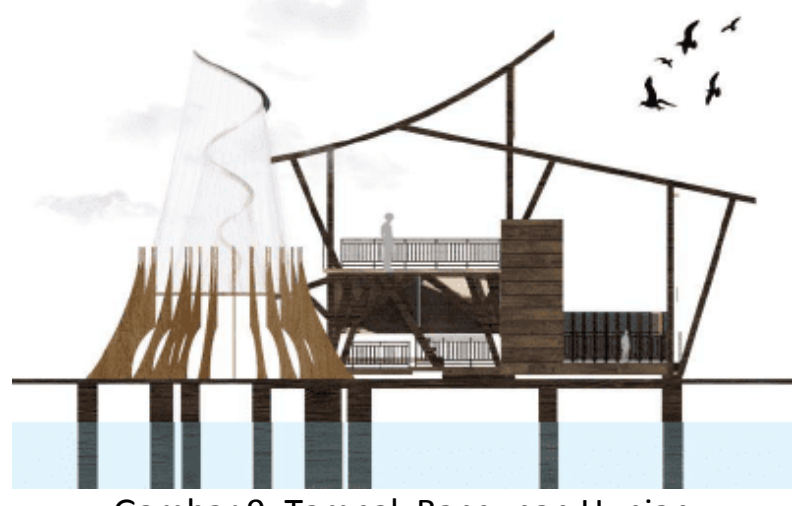

Gambar 9. Tampak Bangunan Hunian

Sumber: Octaviany, 2021

\section{- Resilience}

Struktur Panggung, untuk mengatisipasi kenaikan air sungai dan juga berisi di atas laut, dengan material yang juga tahan cuaca dan air laut (Kayu Ulin).

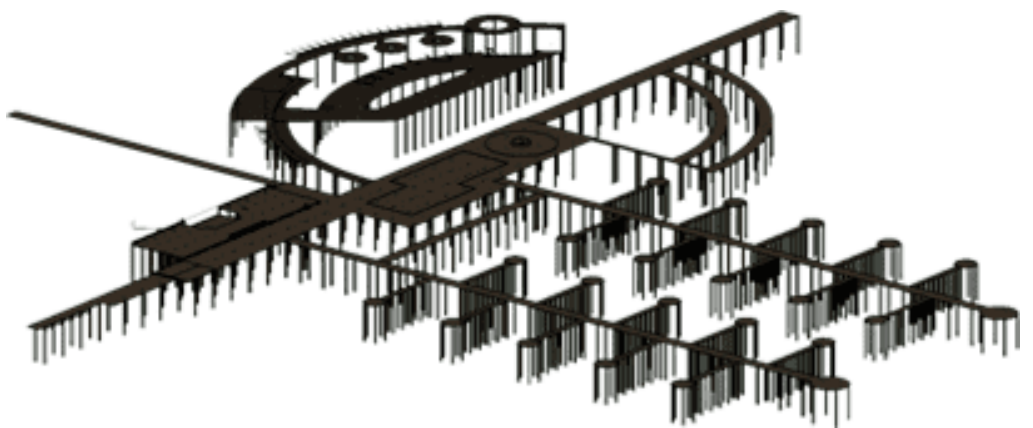

Gambar 10. Struktur Panggung Pemukiman Suku Laut Sumber: Penulis, 2021 


\section{- Adaptation}

Mengadaptasi arsitektur simbiosis Suku Laut kedalam bentuk baru dengan menyesuaikan kebutuhan ruang dan karakter Suku Laut.

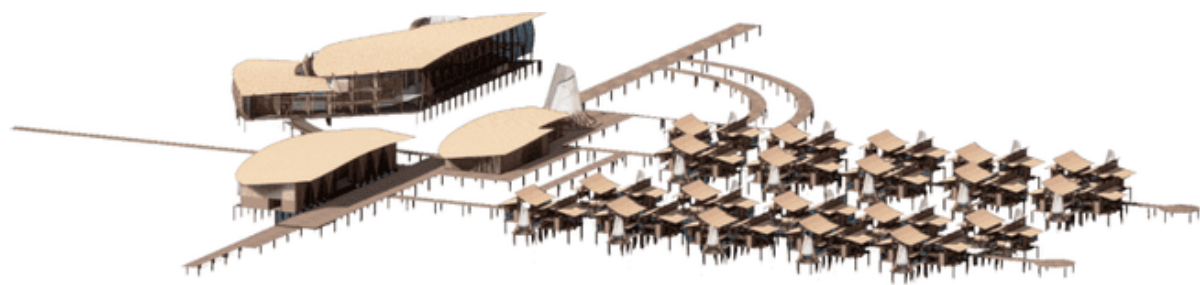

Gambar 11. Pemukiman Suku Laut

Sumber: Penulis, 2021

\section{DISKUSI DAN HASIL}

\section{Tapak Perancangan}

Daik merupakan ibu kota dan pusat pemerintahan kabupaten Lingga. Selain itu, Daik juga merupakan tempat tujuan Suku Laut. Saat Musim Utara, zaman dahulu Suku Laut akan pergi ke Kuala Sungai Daek atau Daek. Suku Laut biasanya berkunjung dan bersosialisasi dengan rekan rekannya dan menikmati pusat kota Daek, kota utama Kabupaten Lingga. Selain itu biasanya mereka juga menetap di pulau sekitar Daik untuk berburu, memperbaiki, dan membuat sampan/kajang baru. Selain itu di dekat Kelurahan Daik terdapat Gunung Daik yang mempunyai sejarah Suku Laut , dimana biasanya mereka menyembah saat mereka melewati Gunung Daik.

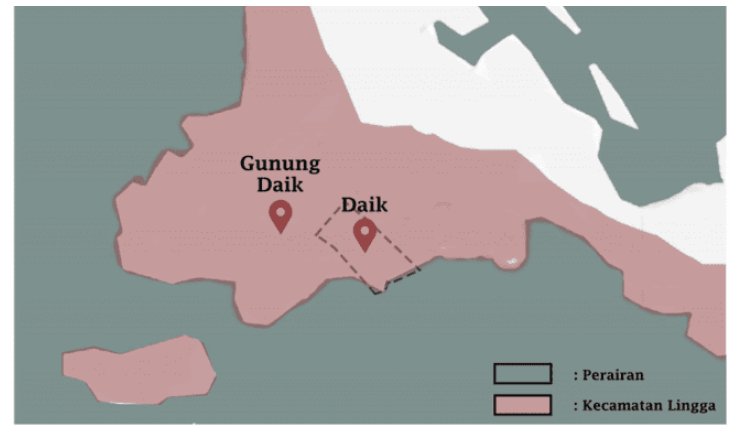

Gambar 12. Daik, Kecamatan Lingga, Kabupaten Lingga, Provinsi Kepulauan Riau Sumber: Octaviany, 2021

Daik memiliki iklim hutan hujan tropis (Af) dengan curah hujan yang tinggi sepanjang tahun. Untuk fasilitas di Daik sendiri merupakan salah satu terlengkap di kabupaten Lingga, salah satunya sekolah dan kesehatan. Biasanya desa-desa sekitar (Desa Tanjungkelit,dll) harus ke Daik untuk sekolah (jenjang SMA) dan untuk ke rumah sakit (apabila sakit parah).

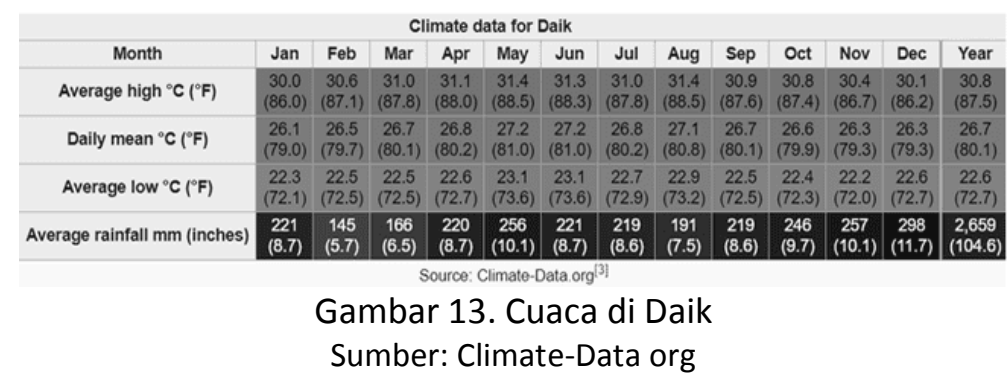

Lokasi tapak berada di Daik, Kecematan Lingga, Kabupaten Lingga, Provensi Kepulauan Riau dengan luasan sekitar $20 \mathrm{ha}$. Tapak ini berada pada Jarak $\pm 1 \mathrm{~km}$ dari pesisir pantai dan untuk akses dapat menggunakan sampan dari dermaga di Daik kurang lbih 500m. Selain itu tapak 
berada di peraian dengan kondisi air yang tenang serta kedalaman kurang lebih $5 \mathrm{~m}$, dengan ketinggaian gelombang biasanya sekitar $50 \mathrm{~cm}$ dan pada pasang surut laut biasanya meningkat paling tingginya sekitar $80 \mathrm{~cm}$.

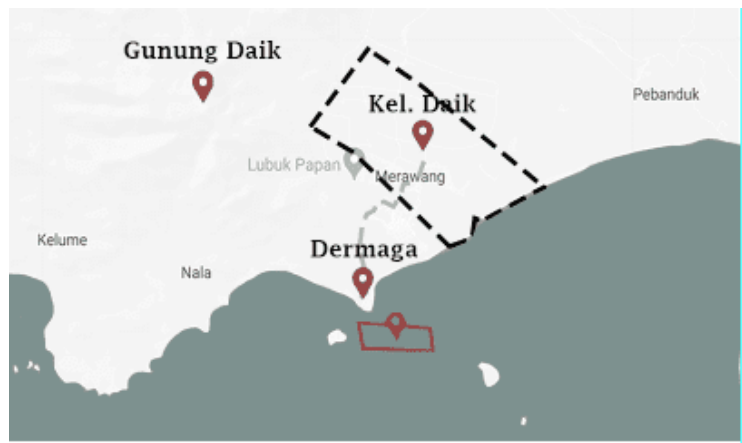

Gambar 14. Daik, Kecamatan Lingga, Kabupaten Lingga, Provinsi Kepulauan Riau Sumber: Penulis, 2021

\section{Konsep dan Desain}

\section{- Strategi Desain}

\section{Step 1. Sirkulasi}

Pengembangan site dengan mengkoneksikan jalur sirkulasi pada Kelurahan Daik dan Pulau Mepar

\section{Step 2. Zoning}

Zona pola Permukiman :

Pola radial merah tua $\rightarrow$ publik (orang luar $\rightarrow$ datang)

Pola linear cokelat muda $\rightarrow$ publik (orang Suku Laut)

Pola linear

$\rightarrow$ private

\section{Step 3. Sun Path Axis}

Bangunan untuk pengeringan ikan asin terletak di arah barat agar proses pengeringan lebih efektif, sedangkan untuk hunian memanfaatkan matahari timur.

\section{Step 4. Spatial Ruang}

Permukiman berorientasi ke dalam untuk menjaga kekerabatan dalam masyarakat. Selain itu, untuk hunian menghadap ke laut agak mempermudah aksesbilitas sampan. Selain itu mempertimbangkan view dari dalam ke luar dan sebaliknya.

\section{Step 5. Blokplan dan Aksesbilitas}

Pembentukan modul disesuaikan dengan unsur-unsur arsitektur simbiosis Suku Laut dan juga lingkungan sekitar, sedangkan untuk aksesbilitas menggunakan dermaga dan jembatan.

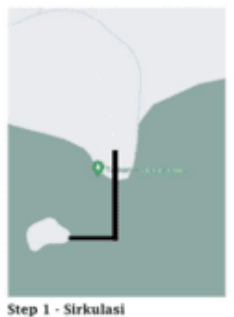

Step 1 - Sirkulasi

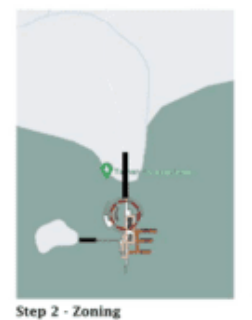

Gambar 15. Strategi Desain
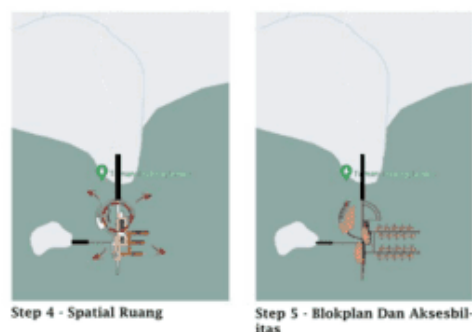

Sumber: Penulis, 2021

\section{- Konsep Perancangan}

Arsitektur simbiosis yang dijelaskan oleh Kisho Kurokawa dapat diterapkan melalui metode hibrida, melalui 3 tahap yang berbeda, termasuk:

1. Eklektik, yaitu menggunakan tipologi bentuk dan arsitektural elemen masa lalu, yang berpotensi menjadidiangkat kembali. 
2. Modificationi, mengubah elemen yang dihadirkanlagi dengan menggeser, menarik, memutar dan membalikkangeometri

3. Kombinasi, menggabungkan unsur-unsur yang telah dimodifikasi dalam desain baru sesuai dengan hierarki dankebutuhan.

Metode hibrida bertujuan untuk melestarikan elemen arsitektur yang memiliki potensi untuk direproduksi dengan teknologi terkini. Oleh karena itu, konsep arsitektur simbiosis dapat diterapkan dengan menggabungkan narasi perjalanan kehidupan Suku Laut tradisional, sekarang, dan kehidupan modern diterapkan baik fungsi ke ruangan atau tipologi proyek untuk menjaga kualitas lingkungan dan keragaman masyarakatnya..

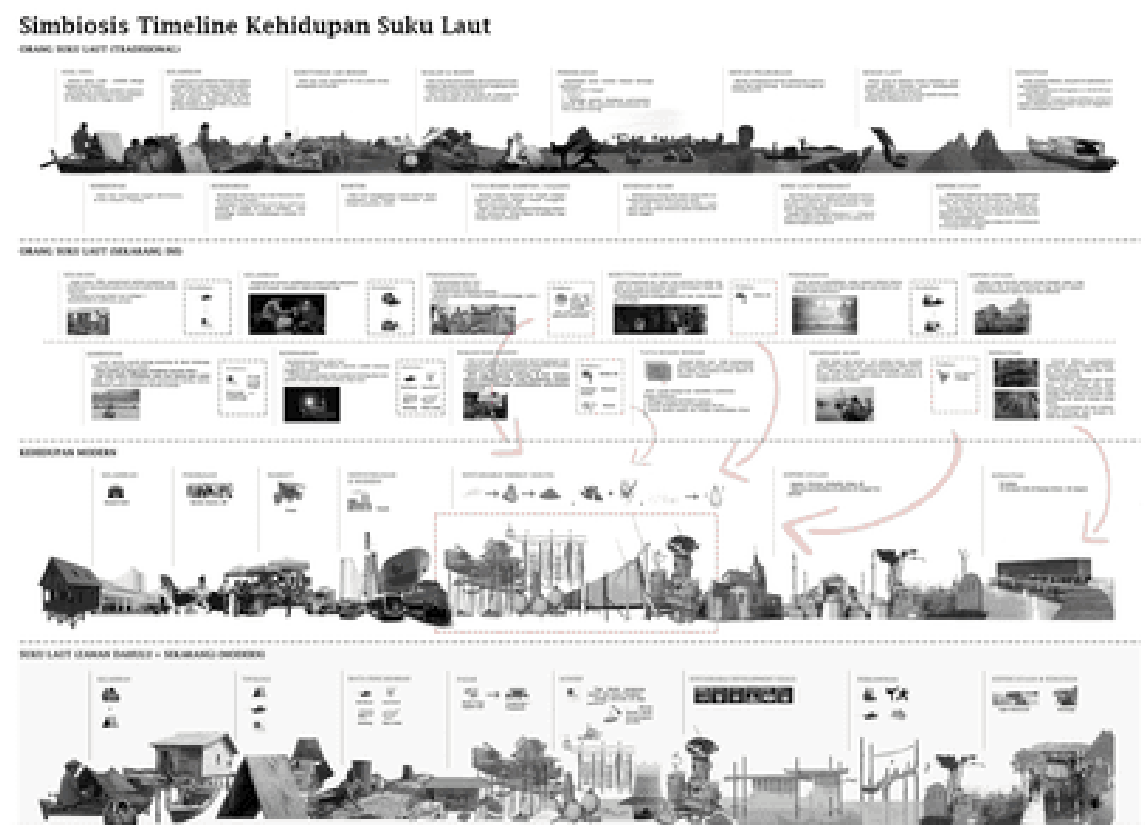

Gambar 16. Simbiosis Timeline Kehidupan Suku Laut

Sumber: Penulis, 2021

\section{- Program}

\section{Hunian}

Kajang dibagi atas 3 bagian, yaitu bagian depan (1) untuk R.berkumpul (tamu) dan pintu masuk, bagian tengah biasanya untuk R.tidur dan berkumpul dan bagian belakang untuk dapur.
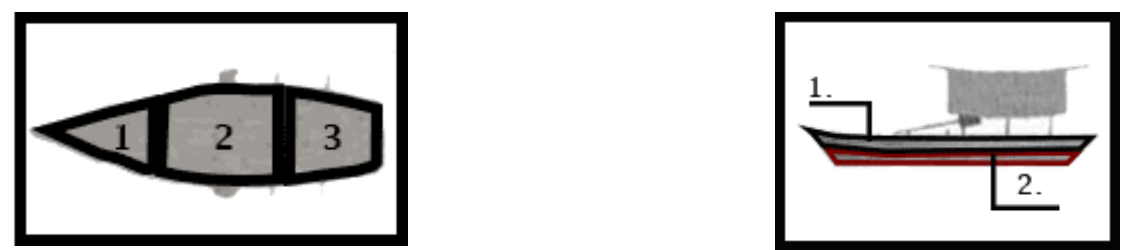

Gambar 17. Tipologi Kajang

Sumber: Octaviany, 2021

Dari tipologi sampan, kemudian di implementasikan menjadi satu pengalaman ruang yang ada (mulai dari hirarki, kebutuhan, fungi) dan juga dari proses perjalanan kehidupan. Selain itu menerapkan konsep "Adaptability" Awalnya pasangan suami istri hnya menempati satu rumah, kemudian kebutuhan ruang bertambah sesuai dengan kebutuhan sehari hari. Sampai pada tahap mereka memilki anak lalu anak mereka memiliki istri atau suami, sehingga dibutuhkan ruang ruang tambahan. 

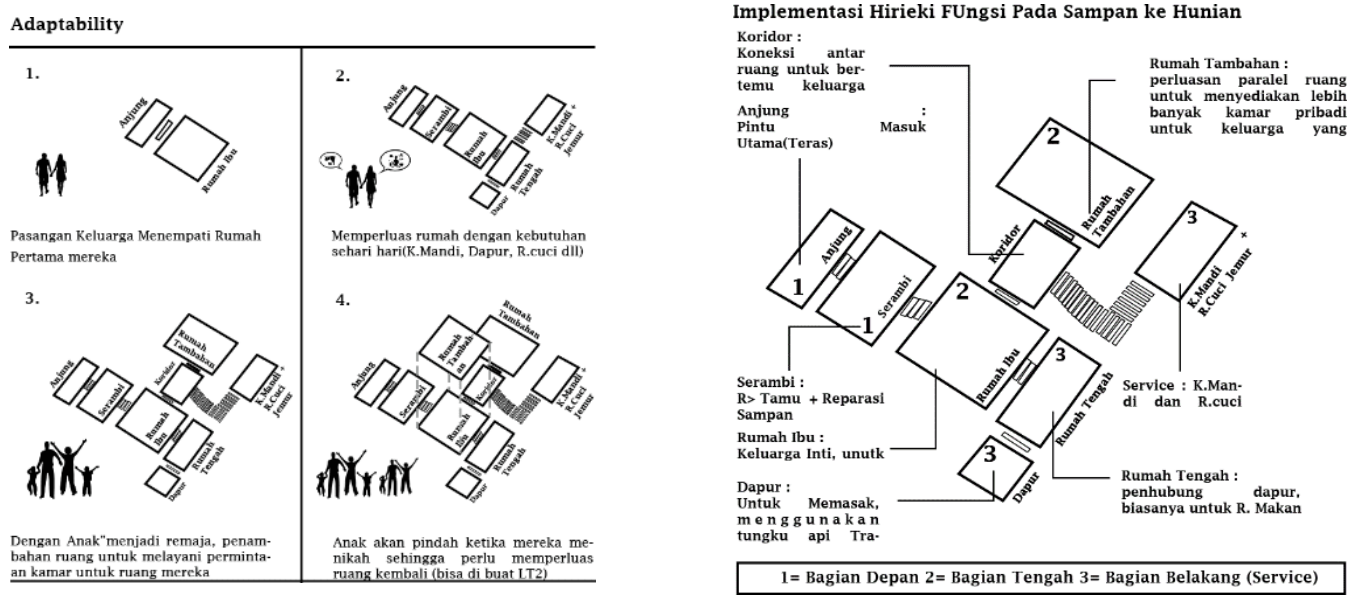

Gambar 18. Konsep Hunian

Sumber: Penulis, 2021

Untuk material bangunan menggunakan bahan material alam, yaitu struktur kayu ulin (tahan air laut), daun nipah/sagu untuk bagian penutup atap, dinding kayu ulin dengan struktur panggung.
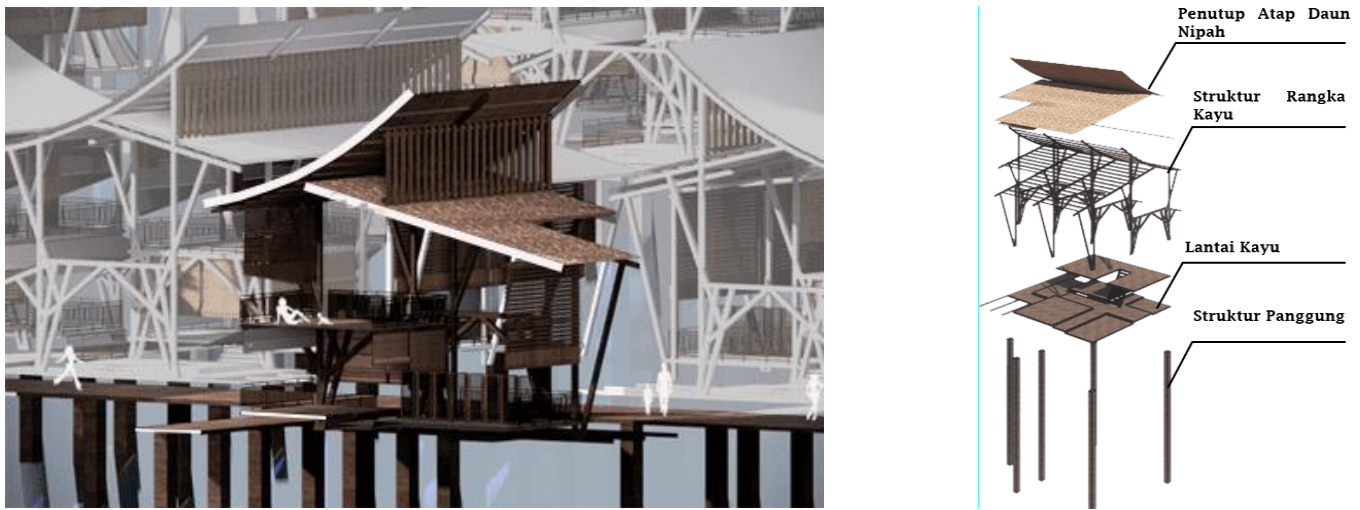

Gambar 19. Potongan Perspektif dan Aksonometri Eksplode Hunian

Sumber: Penulis, 2021

\section{Fog Waterharvesting}

Program ini merupakan hasil pendataan musim Suku Laut, dengan mengolah kelembapan udara menjadi sumber air baru dengan memanfaatkan prinsip evaporasi (penguapan) dan amboo (penyerapan), serta waterharvesting dan air hujan yang cukup melimpah. Sumber air yang dihasilkan melalui udara dengan radius $87 \mathrm{~m} 2$. Kapasitas penyimpanan air yang dapat di tanggung kurang lebih $1000 \mathrm{~L}$ dan material yang digunakan berupa amboo, jarring polyester, tali rami. Biasanya air yang diproduksi dalam Fog Waterharvesting kisaran 5L/ Jam. 


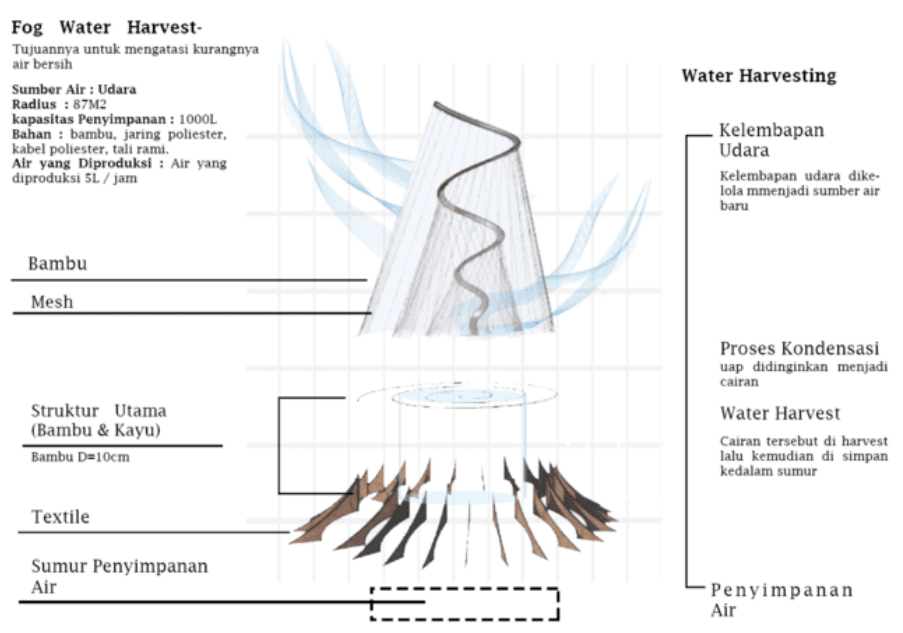

Gambar 20. Aksonometri Eksplode Fog Waterharvesting Sumber: Octaviany, 2021

\section{Aquakultur Restoratif}

Bedasarkan data musim Suku Laut, terdapat beberapa bulan tertentu dimana produktifitas penangkapan ikan menurun. Selain itu 33\% perikanan liar ditangkap berlebih, sementara $60 \%$ lainnya telah mencapai kapasitas maksimum. Aquakultur Restoratif ini diharapkan dapat menyelasaikan masalah, dengan mempergunakan sistem laut alami untuk memproduksi kerang dan rumput laut dalam jumlah besar.

Flora dan fauna dapat meningkatkan kualitas air secara alami, menyaringnya ketika mereka menyerap sinar matahari dan nutrisi dari air laut. Dengan menyerap karbon melalui fotosintesis, perikanan tersebut membantu memerangi perubahan iklim, dan mengurangi pengasaman laut lokal sementara juga menciptakan habitat bagi spesies lain untuk berkembang. perubahan iklim (lewat karbondioksida yang diserap melalui fotosintesis) dan juga dapat meningkatkan habitat spesies lain untuk berkembang. Transisi menuju akuakultur laut restoratif dapat menciptakan peluang kerja bagi penduduk pesisir.

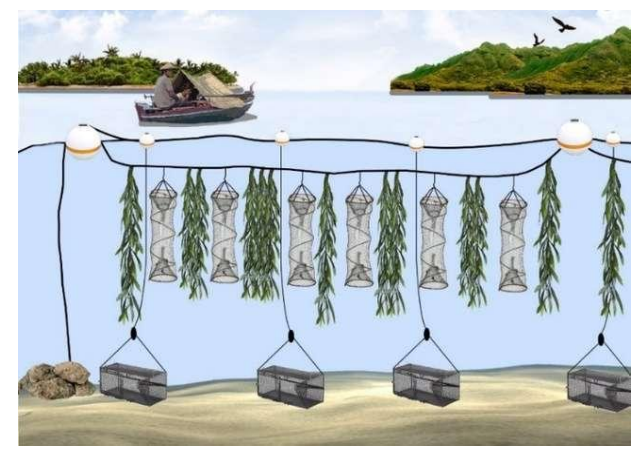

Gambar 21. Aquakultur Restoratif Sumber: penulis, 2021

\section{Pasar}

Mayoritas pekerjaan masyarakat Suku Laut adalah nelayan. Selain menangkap ikan, biasanya mereka juga mengolah ikan tersebut menjadi ikan asin. Pasar menjadi tempat dimana nelayan Suku Laut akhirnya bisa mendistribusikan hasil jualannya tanpa dimanupulasi oleh tengkulak. Pasar tersebut juga tebuka untuk masyarakat Daik dan Kepulauan Mepar untuk membeli ikan dan diperjualkan Kembali. Pasar ini terdiri dari pasar basah (menjual ikan fresh) dan juga pasar kering (menjual ikan asin). 

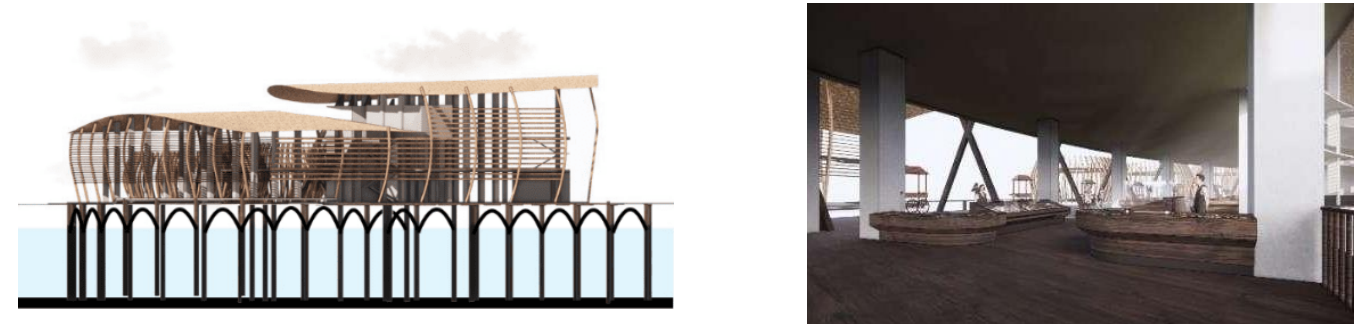

Gambar 22. Eksterior dan Interior Pasar Sumber: Penulis, 2021

\section{Edukasi}

Edukasi pada Suku Laut bertujuan untuk meningkatkan pengetahuan membaca dan menulis serta meningkatkan keterampilan dalam perikanan (membuat jaring, alat, dII) guna untuk membantuk keseharian mereka dalam menangkap ikan. Selain itu esensi dari sekolah itu sendiri juga untuk mengingkatkan kembali sejarah Suku Laut kepada generasi -generasi muda, untuk material menggunakan material Kayu dan juga mengimplentasikan kain tenunan pada fasad.
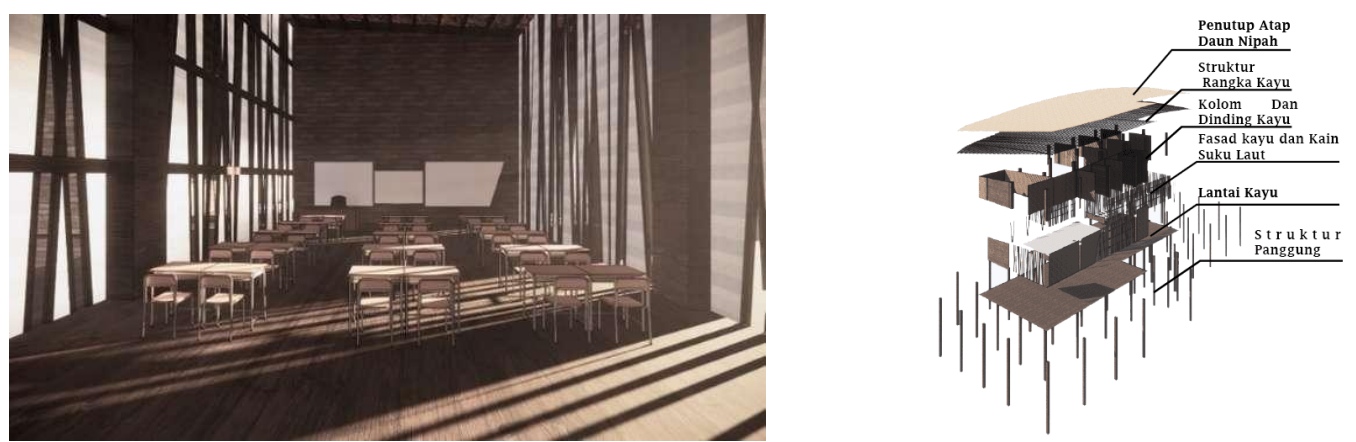

Gambar 23. Interior dan Aksonometri Eksplode Edukasi

Sumber: Penulis, 2021

\section{Ritual}

Bangunan ritual berfungsikan untuk mempertahankan kebudayaan Suku Laut. Dimulai dari upacara adat, ritual kematian, pernikahan dan sebagainya. Suku Laut itu sendiri terkenal dengan kebudayaan yang kental karena masih ada keterikatan dengan nenek moyang dan maritime laut. Selain itu bangunan ini juga terdapat Ruang ibadah untuk masyarakat. Agama yang anut oleh Suku Laut sekarang ini mayoritasnya merupakan agama Islam dan juga masih ada yang aminisme yang masih memepercai nenek moyang.
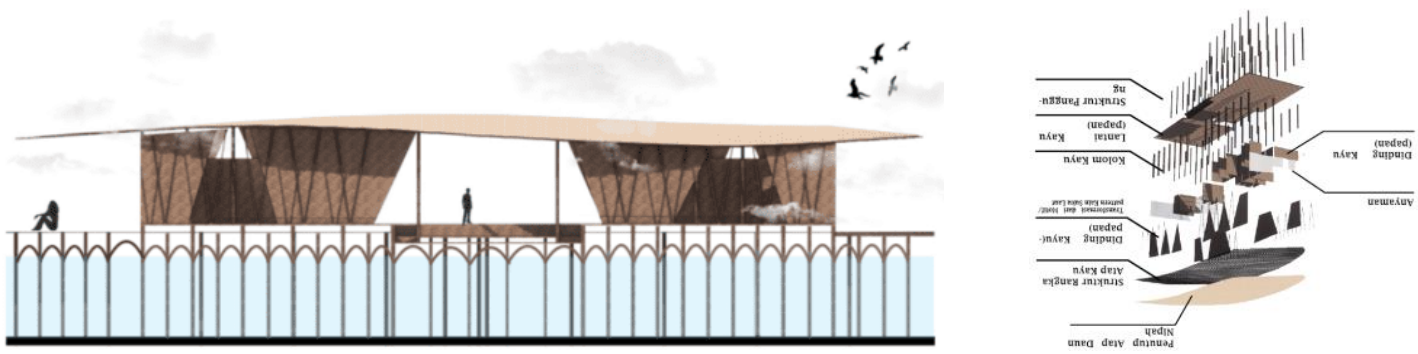

Gambar 24. Eksterior dan Aksonometri Eksplode Ritual Sumber: Penulis, 2021 


\section{KESIMPULAN}

Perkembangan kota sekarang ini telah menjadi masalah bagi Suku Laut. Hibrida merupakan salah satu metode desain arsitektur yang muncul di era postmodern. Selain itu Hibrida juga merupakan kombinasi dari beberapa elemen yang berbeda. Terdapat juga beberapa kriteria desain pemukiman dengan pendekatan arsitektur Simbiosis Suku Laut, seperti penggabungan elemen material, fungsi, hirarki, teknologi modern, kebudayaan Nenek moyang, dll yang hasilnya berupa suatu narasi perjalanan arsitektur Simbiosis Suku Laut dimana perjalanan menyelusuri kehidupan Neo-Kajang diterapkan pada desain "Tipologi Baru Pemukiman Ekologis Suku laut". Melalui tipologi permukiman baru dengan peradaban modern di kombinasikan dengan Suku laut sekarang ini dan dulunya sehingga dapat memahami spiritualitas dan mengembalikan nilai kebudayaan Suku Laut.

\section{REFERENSI}

Chou, C. (2009). The Orang Suku Laut of Riau, Indonesia: the inalienable gift of territory. London: Routledge.

De, A. K., \& De, A. K. (2009). Environment And Ecology. West Bengal: New Age International.

Devall, B. (1985). Deep Ecology. Layton, Utah 8401: Gibbs M. Smith, Inc.

Prawirosusanto, K.M (2015). Orang Laut, Permukiman, dan Kekerasan Infrastruktur. Antropologi Budaya, Fakultas Ilmu Budaya, Universitas Gadjah Mada, Yogyakarta.

Sutanto, A. (2020). Peta Metode Desain. Jakarta.

Sudikno, A. (2017). Memaknai Lokalitas Dalam Arsitektur Lingkungan Binaan. Bidang Sejarah dan Pelestarian Arsitektur. Universitas Brawijaya. Malang.

Studio, A. (2020). Pengertian Arsitektur Neo Vernakular, Ciri-ciri, Prinsip dan Contohnya. Retrieved from Arsitur Studio: https://www.arsitur.com/2017/11/pengertian-arsitekturneo-vernakular.html

Widagdo, M.A., Kusumarini, Y., dan Basuku, L. (2013) Studi Terapan Konsep Metabolisme dan Simbiosis pada Bangunan Karya Kisho Kurokawa. Program Studi Desain Interior. Universitas Kristen Petra, Jurnal Intra. Vol. 1, No. 2 
